MÜHELYTANULMÁNYOK

DISCUSSION PAPERS

MT-DP - 2016/1

The 'fit' between forward-looking activities and the innovation policy governance sub-system

A framework to explore potential impacts

ATTILA HAVAS - K. MATTHIAS WEBER 


\section{Discussion papers}

MT-DP - 2016/1

Institute of Economics, Centre for Economic and Regional Studies, Hungarian Academy of Sciences

KTI/IE Discussion Papers are circulated to promote discussion and provoque comments. Any references to discussion papers should clearly state that the paper is preliminary. Materials published in this series may subject to further publication.

The 'fit' between forward-looking activities and the innovation policy governance sub-system A framework to explore potential impacts

Authors:

Attila Havas senior research fellow

Institute of Economics - Centre for Economic and Regional Studies

Hungarian Academy of Sciences

e-mail: havas.attila@krtk.mta.hu

K. Matthias Weber

AIT Austrian Institute of Technology $\mathrm{GmbH}$, Donau-City-Straße 1, 1220 Vienna, Austria e-mail: matthias.weber@ait.ac.at

January 2016

corrected version, July 2016 


\title{
The 'fit' between forward-looking activities and the innovation policy governance sub-system \\ A framework to explore potential impacts
}

\author{
Attila Havas - K. Matthias Weber
}

\begin{abstract}
Forward-looking activities (FLAs) can influence innovation systems in various ways to a significant extent. This paper focuses on changes induced by FLAs in the innovation policy governance sub-systems (IPGSs) of the national innovation system. Our knowledge is surprisingly limited even on this subset of FLA impacts, despite several decades of practice and non-negligible analytical efforts. We identify key features of FLAs and IPGSs and explore hypotheses on the likely 'fit' between different types of FLAs and various IPGSs. Countries selected to illustrate the relevance of our analytical framework include Germany, Greece, and Hungary. Our intention is contribute to a more refined theory building concerning the role and likely impacts of FLAs. Further, as a better understanding of impacts supports the design of more appropriate and effective FLAs, as well as more insightful evaluation of FLAs, this approach is of practical relevance, too.
\end{abstract}

Keywords: Forward-looking activities (FLAs); Impacts of FLAs; Innovation policy governance sub-systems (IPGSs); Key characteristics of FLAs and IPGSs

Journal of Economic Literature (JEL): B52, O30, O38, O39

Acknowledgments

This paper is a revised and extended version of a paper presented at the $5^{\text {th }}$ International Conference on Future-Oriented Technology Analysis (FTA), entitled Engage today to shape tomorrow, held in Brussels on 27-28 November 2014. 


\title{
A jövőt formáló elemzési tevékenységek és az innovációpolitika irányítási rendszere közötti illeszkedés Elemzési keret a várható hatások feltárására
}

\author{
Havas Attila - K. Mathias Weber
}

\section{Összefoglaló}

Az elmúlt évtizedekben egyre több országban törekszenek arra, hogy meghatározzák az előre látható fejlődési folyamatokat, illetve befolyásolják a fejlődés irányát és ütemét a gazdasági és társadalmi szereplők, valamint a kutatók közötti párbeszéd és együttmúködés erősítésével, s erre támaszkodva a döntések összehangolásával. Ezek a tevékenységek - az angol szakkifejezés rövidítésével: FLA - elsősorban a nemzeti innovációs rendszerek (NIR) szerkezetére és müködésére hatnak, s ezen keresztül befolyásolják a versenyképességet és az életminőséget. Ebben a tanulmányban a NIR egyik fontos alrendszerére, az innovációpolitika irányítási rendszerére (IPIR) gyakorolt lehetséges hatásokat vizsgáljuk, mivel még e viszonylag szűk területről is meglehetősen keveset tudunk. Különböző FLA-módszerek terjedtek el az egyes országokban, és az IPIR is sokféle lehet. Ezért először az FLA-módszerek és az IPIR fontos jellemzőit emeljük ki, majd egyes FLA-módszerek és eltérő IPIR-ek illeszkedésére vonatkozó hipotéziseket vizsgálunk meg. Három nemzeti előretekintési programot - a görögöt, a magyart és a németet - részletesebben is elemzünk, ezeken keresztül mutatjuk be a javasolt elemzési keret érvényességét. Ez az elemzési keret elméleti és gyakorlati célokat is szolgálhat. Egyrészt hozzájárulhat ahhoz, hogy pontosabb, megalapozottabb elméletet alkossunk az FLA-módszerek szerepéról és várható hatásairól. Másrészt segítheti a megfelelő FLA-módszerek kiválasztását a lehetséges fejlődési folyamatok feltárására és befolyásolására irányuló tevékenységek tervezése során, illetve az ilyen tevékenységek hatásainak utólagos értékelését, s ezzel a hatásosabb szakpolitikai intézkedések kidolgozását.

Tárgyszavak: a jövőt formáló elemzési tevékenységek (FLA), az FLA hatásai, az innovációpolitika irányítási rendszere (IPIR), az FLA és az IPIR jellemzői

Journal of Economic Literature (JEL): B52, O30, O38, O39

\section{Köszönetnyilvánítás}

A tanulmány a $5^{\text {th }}$ International Conference on Future-Oriented Technology Analysis (FTA), Engage today to shape tomorrow címü, 2014. november 27-28-án Brüsszelben rendezett konferencián elhangzott előadás átdolgozott, kibővített változata. 


\section{Table of Contents}

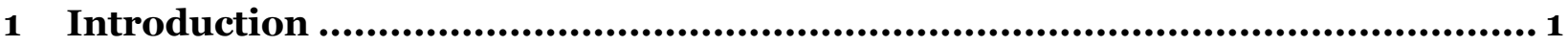

2 Conceptual framework ............................................................................2

2.1 Evolutionary theorising, FLAs and implications for STI policy .....................................2

2.2 Governance of innovation systems ..........................................................................

2.3 Systematising the relationship between forward-looking activities and innovation

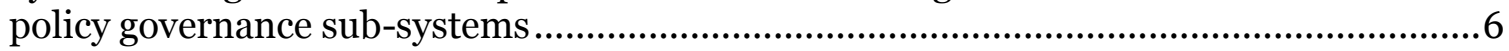

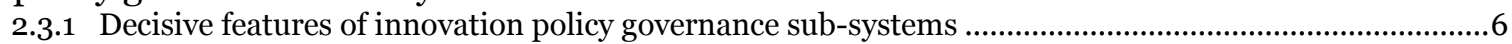

2.3.2 Key characteristics of forward-looking activities.....................................................................................

2.4 The main hypothesis: the compatibility between the IPGS and FLA ..............................9

3 Illustrative cases ............................................................................................ 10

3.1 Greece: the National Technology Foresight Programme ...................................................11

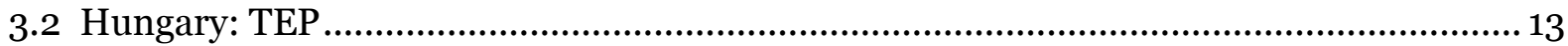

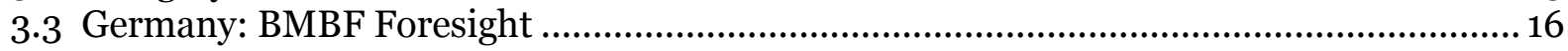

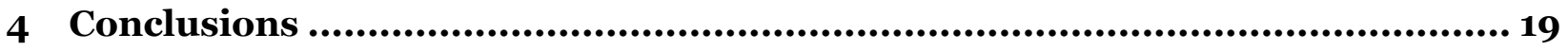

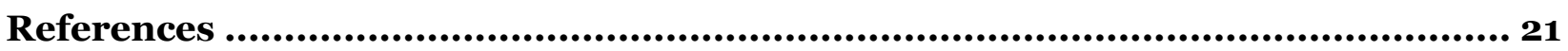




\section{INTRODUCTION}

Forward-looking activities (FLAs) have been in the toolbox of science, technology and innovation (STI) policies for several decades. They can influence national, regional and sectoral innovation systems in various ways to a significant extent by introducing new policies and 'rules of the game', as well as creating new 'nodes' in these systems (e.g. new policy-making bodies, research and innovation performing organisations, or those facilitating these activities). Of these many types of potential changes this paper focuses on changes induced by FLAs in the innovation policy governance sub-systems (IPGS) of the national innovation system (NIS). Our knowledge is surprisingly limited even on this subset of FLA impacts, despite several decades of practice and non-negligible analytical efforts. What we know is based on individual case descriptions or evaluation reports - rather than systematic comparative analyses.

A possible reason for this knowledge gap is the wide variety of FLA methods and approaches ranging from highly participatory to expert-based ones and from creativity-driven to evidencebased exercises. Further, R\&D and innovation (RTDI) activities, to be influenced by FLAs, are complex in nature. Complexity applies a fortiori to innovations systems, as shown by evolutionary economics. Thus, reconsidering existing theories on innovation systems and our current knowledge on FLAs in a new, systematic way is likely to improve our understanding.

The innovation policy governance sub-system contributes to identifying and prioritising certain policy needs and problems in a given innovation system, on the one hand, and translates insights from FLAs into policy actions, on the other. Overall, analysing actual or exploring potential impacts of FLAs on national innovation systems requires handling a great deal of diversity, both with regards to FLAs and the IPGSs, in which they are embedded.

Hence, we present a framework as the basis for exploring hypotheses on the likely 'fit' between FLAs and IPGSs; or from a different angle, on the potential impacts of different types of FLAs in different settings. The relevance of this proposed framework is to be tested by reconsidering actual cases of FLAs, relying on available analyses. This framework could be used by policy-makers who consider launching an FLA project, practitioners designing that, as well as by analysts conducting ex-post evaluations.

The paper draws on a rich literature covering various fields of theories from innovation economics, governance studies, and policy impact/ evaluation research, as well as case studies and the authors' practical experience. The conceptual framework, mainly relying on evolutionary economics of innovation and the policy governance literature, is introduced in section 2. The focus is on identifying key features of FLAs, on the one hand, and of IPGSs, on the other. While 
we believe that our approach can be extended beyond national innovation systems (to sectoral or regional innovation systems), here we concentrate on the national level in order to limit the complexity of our analyses. The possible use of the proposed framework is illustrated in section 3 by brief analyses of actual FLA projects conducted in Germany, Greece, and Hungary. Finally, section 4 offers some conclusions regarding the wider applicability of this framework both for ex-post evaluation and design (or ex-ante impact analysis) of FLAs.

\section{CONCEPTUAL FRAMEWORK}

FLAs do not have a single, all-encompassing theory to underpin them; rather, they rely on a range of - somewhat overlapping - theories and methods, including evolutionary and institutional economics of innovation; sociology of science and technology; actor-network theories; political sciences analyses of policy processes; theories on communication, cooperation, and participation; as well as decision-preparatory, (project) management and futureoriented methods and techniques. ${ }^{1}$ This list is far from being exhaustive, and most likely several disciples of these theories would change the grouping or the 'labelling' used here. That might be an interesting discussion, indeed, for theoretical purposes. Yet, our intention here is just to indicate the complex nature of FLAs, rather than attempting to provide a meticulous, comprehensive treatise on the congruence of these theoretical bases, let alone to construct a comprehensive, definitive theory of FLAs.

\subsection{EVOLUTIONARY THEORISING, FLAS AND IMPLICATIONS FOR STI POLICY}

Our discussion mainly draws on evolutionary economics of innovation and political sciences, in particular the policy governance literature. The former provides useful observations to understand the relevance of FLAs from different angles. Uncertainty and change are the underlying notions both for forward-looking activities and analyses on innovation processes and systems.

A principal thesis in evolutionary economics is that

"innovation involves a fundamental element of uncertainty, which is not simply the lack of all the relevant information about the occurrence of known events, but more fundamentally, entails also (a) the existence of techno-economic problems whose solution

\footnotetext{
${ }^{1}$ The order, in which these disciplines are listed here, does not indicate their importance in any sense. The literature on these strands of theories is so huge that any attempt to identify the most important contributions would be pretentious; hence only a few pieces of work can be referred to here, in a somewhat arbitrary way: Bauchspies et al., 2006; Bijker, 2010; Dosi et al. (eds), 1988; Edquist (ed.), 1997; Fagerberg et al. (eds), 2005; Fagerberg et al., 2012; Freeman, 1994, 1995; Georghiou et al. (eds), 2008; Hackett et al. (eds), 2008; Haegeman et al., 2013; Hall and Rosenberg (eds), 2010; Jasanoff et al. (eds), 1995; Joerges and Nowotny (eds), 2003; Latour, 2005; Lundvall (ed.), 1992; Martin, 2012; Metcalfe, 1998; Nelson (ed.), 1993; Nelson, 1995; and Pavitt, 1999.
} 
procedures are unknown, and (b) the impossibility of precisely tracing consequences to actions" (Dosi, 1988: 222 - emphasis added).

Thus, optimisation, the cornerstone of mainstream economics, is excluded on theoretical grounds.

The notion of uncertainty is of fundamental importance not only for theoretical analyses; it also has several policy implications. First of all, relying merely on analyses of the current state, performance and deficits of innovation systems as the basis for devising innovation policy is insufficient: this approach ignores the fact that the future can be (structurally) different from the past and the present. No doubt, tackling current shortcomings is necessary, but - in view of uncertainty - it must be complemented by forward-looking approaches to policy development and governance.

Secondly, dealing with future developments has been pursued for many years under the heading of forecasting, which is based on the extrapolation of (supposedly) known trends. The space of events, in which forecasting can be meaningful is strictly limited: the only certain - and thus easily predictable - feature of innovative activities is that most of the underlying technological and business trends can change quite radically even in the space of 10-15 years. ${ }^{2}$ The scientific and policy relevance of forecasting is thus limited, as it ignores the existence of fundamental uncertainty associated to innovation.

From a policy perspective, therefore, new methods are required, which can take uncertainty into account during a decision-preparatory process. Certain types of FLAs, most notably foresight, are prominent from this angle, for two reasons. First, it is capable of dealing with uncertainty by devising multiple (fundamentally/ qualitatively different) 'futures' (visions of future, future states). Second, participatory FLAs - again, foresight processes - can reduce uncertainty, too, because participants can align their endeavours once they arrive at a shared vision. To this effect, however, it is a necessary condition to involve the major stakeholders, who not only can enrich outlooks on multiple futures drawing on their wide-ranging knowledge, experience and perspectives, but also significantly influence the underlying trends by shaping the strategies or policies of their respective organisations, be they government agencies, businesses, research organisations, NGOs, unions, or other types. Their shaping ability, of course, depends on the issues in question, as well as on the political and decision-making culture

\footnotetext{
${ }^{2}$ Obviously, there are certain trends, e.g. demographic ones, which are not directly influenced by RTDI activities, on the one hand, and their 'stability' (predictability) extends to a much longer time horizon (in this case around 40-50 years), on the other. Also, the pace and intensity of RTDI activities - and hence their impacts on major technological, business, societal and environmental developments - vary significantly across time (different historical periods) and countries (socio-economic systems).
} 
of the 'entity' conducting a foresight programme: international organisations or regions, nation states, sub-national regions, business associations, groups or individual firms, cities, etc.

Innovation studies have also shown that innovators are not lonely champions of new ideas. While talented individuals might develop radically new, brilliant scientific or technological concepts, successful innovations require different types and forms and knowledge, rarely possessed by a single organisation. A close collaboration among firms, universities, public and private research organisations and specialised service-providers is, therefore, a prerequisite of major innovations. Forms of innovation co-operation can vary widely from informal communications through highly formalised RTDI contracts to alliances and joint ventures (Freeman 1991, 1994, 1995; Lundvall and Borrás, 1999; OECD, 2001; Smith, 2000, 2002; Tidd et al., 1997). Thus, conscious network-building efforts of participatory FLAs are crucial, indeed - as well as their unintended impacts on networking. 3

Evolutionary accounts of innovation lead to sobering lessons concerning the very nature of policy-making, too: in a world of uncertainty, policy cannot bring about the optimum either. Further, given the importance of variety, selection and uncertainty, the potentially successful policies are adaptive ones, that is, they rely on, and learn from, feedbacks from the selection process, which is, in turn, leads to further variation (Metcalfe and Georghiou, 1998). In other words, policy formation is increasingly becoming a learning process (Lundvall and Borrás, 1999). Several types of policy failures have also been identified by analysts (e.g. Edquist, 2011; Malerba, 2009; Metcalfe, 2005; and Smith, 2000), of which at least three types can be tackled by FLAs, namely the lack of understanding of sectoral characteristics/ dynamics, poor (or lack of) vision building, and ineffective co-ordination. Hence, certain types of FLAs can contribute to design appropriate policies: more 'robust' policies can be devised when (i) multiple futures are considered, and (ii) stakeholders, given their diverse backgrounds, bring wide-ranging accumulated knowledge, experience, aspirations and ideas into policy dialogues.

\subsection{GOVERNANCE OF INNOVATION SYSTEMS}

In line with these evolutionary insights into what policy can deliver (or not) with regard to innovation, governance studies have also recognised the limits to hierarchical political steering (Peters and Pierre, 1998). This problem is not specific to innovation; it applies to many other policy domains as well. Social systems show complex features such as self-organisation and self-

\footnotetext{
3 The benefits in this respect include strengthened existing networks, formation of new ones, and more generally, enhanced communication and co-operation among different actors involved in innovation processes.
} 
referential behaviour, which is why they easily escape any attempt of targeted control (Weber, 2009).

The initial response to these recognised limits to control is reflected in the growing prominence of context control (Willke, 1995) and more specifically in the rise of the so-called New Public Management principles (NPM). Without going into details of the NPM debate, contractual and market relations between ministries/ governments as principals and subordinate organisations (e.g. universities, funding agencies, research organisations, etc.) as agents have been introduced. This form of institutionalising the interfaces between government and other organisations recognises the autonomy of these organisations, but subjects them to strategic goal-definition and resource allocation. Hierarchy as an organising principle is thus still maintained, while market relations are also used for operationalising political control.

In the meantime, it has become obvious that NPM is facing a number of challenges. One of these concerns the autonomy of the agents in defining their strategies autonomously, due to the knowledge gap between them and their principals. A second challenge, of particular relevance in the context of FLAs, concerns the lack of co-ordination between highly autonomous selfgoverning organisations. Coherence of policy strategies in and beyond the innovation policy domain is crucial for addressing major societal challenges and realising transformative changes, but no government can ensure that coherence by way of centralised hierarchical steering. This challenge is exacerbated by the fact that coherence needs to be sought not only with regard to the strategies and actions of public actors, but also with regard to private sector agents.

The response of governance studies to these challenges consists of proposing network-type arrangements as a means to induce a higher degree of coherence and co-ordination of strategies and actions on an otherwise segmented landscape of policy domains. In fact, the notion of 'governance' is already a reflection of the need to understand change processes in society as the result public as well as private and third sector activities (Rhodes, 1997). Foresight, understood as a forward-looking and participatory activity dealing with open futures, is a means to reinforce network-based co-ordination and coherence of actor strategies.

In the context of innovation, policy governance sub-systems (IPGSs) are in charge of overseeing the governance of STI policy processes, which involve several non-governmental actors, too. Collective initiatives are launched, problem perceptions and agendas defined, new structures and institutions to steer and shape innovation systems established. Foresight can play a major role in preparing and implementing such activities triggered by the IPGS. It is likely to have a major impact also on the IPGS itself as well, by promoting the use of a participatory and 
pluralistic approach to decision-making and policy implementation. As already noted, policysetting processes are learning processes, just as innovation processes, and FLAs are important policy tools to shape innovation systems and future innovation activities. IPGSs are also the locus where these learning processes need to be triggered and overseen.

It is against this backdrop that the nature of policy formation processes and the policy rationale of FLAs should be clearly understood (Havas, 2005), as a precondition for achieving a good 'match' between an FLA project and the respective IPGS, and thus for enhancing the effectiveness of FLAs to be conducted. Systematising this relationship between the IPGSs and FLAs is the main ambition of this paper.

\subsection{SYSTEMATISING THE RELATIONSHIP BETWEEN FORWARD-LOOKING ACTIVITIES AND INNOVATION POLICY GOVERNANCE SUB-SYSTEMS}

\subsubsection{Decisive features of innovation policy governance sub-systems}

Policy governance sub-systems (IPGSs) are a key part of innovation systems. Their role is to oversee the strategic orientation and guidance of the transformation of innovation systems. ${ }^{4}$ In other words, the IPGS is a locus where the priorities, organisational and institutional settings, and regulations are defined that guide or provide incentives for decision-making by RTDI performers.

FLAs are often initiated to prepare and trigger changes in innovation systems, such as a structural and institutional change processes or the definition of new thematic agendas. The results of FLAs by definition refer to future developments and spark implications with regard to strategies of private and public sectors actors, as well as of intermediaries in the innovation system.

We argue that FLAs can play a major role in guiding the strategic orientation of innovation systems if they are well connected to, or embedded in, the policy governance sub-system. For deriving generalised conclusions regarding the match or mismatch between a certain FLA project and a given IPGS, it is thus important to characterise IPGSs by identifying their decisive features from this angle.

In line with our emphasis on national innovation systems and corresponding FLAs we highlight key dimensions that characterise IPGSs at the same level. An IPGS is embedded in the

\footnotetext{
4 Just to avoid some potential misinterpretations, besides policy-making (public) bodies, various RTDI performers (universities, public and private non-profit research organisations, firms) as well as other major stakeholders (interest groups, etc.) are also major actors of the innovation policy governance systems: they can, and indeed do, influence STI policies in various ways.
} 
overall governance system, and hence we borrow insights from the general governance literature in order to identify key dimensions to characterise IPGSs.

IPGSs can be characterised along several dimensions, which - for reasons of simplicity - we define in binary terms:

- Power structures: Political power can be organised in different forms. Governance can be centralised in a few hands, with a quite centralised hierarchical control. As there is usually no single centre of power, it is appropriate to speak of an oligopolistic setting as one extreme of the spectrum. Opposed to such a centralised model are decentralised approaches to governance, i.e. IPGSs where power is distributed among many actors. As examples of the former, Central and Eastern European countries can be mentioned (until the early 1990s), but also some Asian countries with autocratic and strongly hierarchical features. In contrast, several Western European countries have developed systems of distributed governance, with many different players and different policy levels and in different policy areas contributing to the definition of innovation policy (Kuhlmann, 2001). The more recent discussions on governance models stress the critical role of networks for bridging between different policy domains and levels, in spite of these being organised along the lines of hierarchical systems. In other words, networks aim to bring in elements of decentralisation in structurally oligopolistic IPGSs.

- Political-administrative culture: A second important dimension of IPGSs refers to the political-administrative culture. As main archetypes, we distinguish an antagonistic IPGS from a consensual one. An antagonistic governance model is characterised by strong majority-led elements that is balanced by regular changes in power. But it is also about strictly demarcated policy domains and levels, where defending the respective terrain is a key part of the underlying logic. The consensual model is, on the contrary, driven by a permanent involvement of all relevant stakeholders in decision-making, even if they formally are not in power. Changes in government thus do not lead to major ruptures in policy, as positions of all actors have already been integrated in policies. The distinction between the two extremes can be exemplified suitably by the British model of governance, on the one hand, which relies on antagonistic and majority principles ('the winner takes all'), and the Dutch and Scandinavian democracies, on the other, which have strong elements of consensus orientation. 5 Countries with a stronger corporatist tradition like Austria or Germany fall also within the consensual category, but the corporatist model also tends to show more oligopolistic features than the 'open' democracies (Rhodes, 1997). In between these two extreme archetypes, different variants are possible. Purely consensusoriented systems could easily enter into stalemate situations, because political choices often imply that there will be winners and losers. ${ }^{6}$ Most, if not all, countries currently struggle to find ways to achieve better horizontal and multi-level co-ordination to tackle complex policy problems.

\footnotetext{
5 The 'varieties of capitalism' literature provides deeper insights into this type of differentiation (Hall and Soskice (eds), 2001; Hall and Thelen, 2009).

6 The debate about the construction of new power grids as a pre-condition for the German 'Energiewende' is a good example.
} 
- Reliance on strategic policy intelligence: Governance systems differ in terms of the extent to which policy preparation tools (PPTs) are used to develop, implement and monitor policies. FLAs are just one among other types of tools used to prepare policies. PPTs also include, for instance, monitoring and evaluation activities, formal and informal consultation mechanisms (e.g. technology assessment), and system analysis. It seems useful to distinguish countries that rely on a whole spectrum of PPTs systematically and consciously to support the governance process and countries that use PPTs rather sparsely.

\subsubsection{Key characteristics of forward-looking activities}

There are several taxonomies of FLAs, 7 but with regard to the impact of FLAs, it seems more appropriate to concentrate on the nature of the process and the role it can play in the NIS. We suggest using the following three dimensions:

- Visibility of FLAs: When an FLA project is given pronounced publicity we can speak of a highly visible FLA. These FLAs can have a clearly identifiable impact, if appropriately geared to the conditions of the given IPGS. In these cases, though, synergies with other PPTs are not fully exploited (if at all). In contrast, a 'hidden' FLA project is run in parallel with the use of a broad range of other PPTs. Its impacts, therefore, could easily be attributed to other PPTs. The potential for synergies among various PPTs, and thus for more appropriate and effective STI policies, is higher though when an FLA project is embedded in this integrated set of PPTs.

- Degree and type of participation: Highly participatory FLAs can exert an influence on the NIS through a range of channels. They allow establishing an interface between different types of NIS actors. In other words, they contribute to 'wiring up' the NIS (Martin and Johnston, 1999) because they are participatory. They also promote broad-based learning about the system (its elements and characteristics; backgrounds and views of actors, tensions among them) and facilitate the implementation of policy proposals. ${ }^{8}$ In contrast, certain FLAs are much less participatory and are constructed as policy advisory processes. These usually rely on a small group of experts to support a specific policy initiative and thus are likely to have a strong - and easily identifiable - policy impact.

- Purpose: We distinguish FLAs aiming to set thematic priorities from those aiming to induce systemic changes. Many FLAs are aimed improving the performance of a NIS by identifying appropriate S\&T priorities and focussing resources on those domains. A different type of objective is to induce significant structural changes in the NIS. These FLAs can aim at overcoming various types of lock-in situations, including sectoral/ thematic ones in various S\&T fields (failures to generate new technological opportunities, lock-in in inferior technology) or structural ones (e.g. weak learning capabilities of firms, poor business-academia co-operation, lack of internationalisation). These FLAs are likely

\footnotetext{
7 See for instance the five 'generations' of foresight (Miles et al., 2008), extended from the original version of three 'generations' suggested by Georghiou (2001). Another approach considers the rationales of FLAs, i.e. whether they focus on identifying promising S\&T fields, lucrative techno-economic opportunities, or emerging socio-economic challenges (Havas, 2005, 2011).

8 In case of a foresight programme, participants are owners of a shared vision, as well as the policy proposals derived from that vision; and as they are also actors in the NIS, they can act upon these proposals.
} 
to question the prevailing power structures and challenge the dominant constituencies of actors, and thus are inevitable when there is a strong need to overhaul the IPGS itself (e.g. in terms of STI policy rationales, overall decision-making culture and methods to support it; efficacy of STI policies; efficiency of public spending). High level of participation tends to strengthen the transformative potential of FLAs by creating new 'wires' in the NIS.

\subsection{THE MAIN HYPOTHESIS: THE COMPATIBILITY BETWEEN THE IPGS AND FLA}

The underlying hypothesis of our paper is that the closer the 'fit' between a chosen type of FLA and the innovation policy governance sub-system in which it is (to be) conducted, the stronger and more favourable the impacts of the FLA project are expected to be. ${ }^{9}$

The notion of 'fit' should not be understood as a static and linear concept. FLAs and IPGSs influence each other in the course of time. There are interactions among them. The type of FLA is likely to exert an influence on the nature of the innovation policy governance sub-system: a non-participatory FLA project would reinforce the oligopolistic character of an IPGS, while a participatory FLA would tend to open up the IPGS towards more distributed decision-making. In the longer run, and with ensuing tensions, of course such an effect might even lead to an FLA having a transformative impact on the IPGS. In fact, an initial lack of 'fit' between IPGS and FLA might enable transforming an IPGS under specific favourable circumstances.

The three plus three 'dimensions' proposed in section 2.3 lead 8 to combinations both for FLAs and IPGSs. Obviously, we cannot analyse all the possible 64 combinations in a single paper, and thus pick those FLAs that are intended to induce systemic changes (that is, 4 of the 8 possible combinations of FLAs, Table 1), and discuss briefly how the different dimensions of the IPGS would hinder or facilitate a certain FLA of these four.

Table 1

Four types of FLA projects for systemic changes

\begin{tabular}{|l|c|c|}
\hline & $\begin{array}{c}\text { Low level of } \\
\text { participation }\end{array}$ & $\begin{array}{c}\text { High level of } \\
\text { participation }\end{array}$ \\
\hline Highly visible & FLA Task Force & FLA Dialogue \\
\hline Hidden among other PPTs & FLA Analysis & FLA Culture \\
\hline
\end{tabular}

FLA Task Force would be compatible with a distributed and antagonistic IPGS, in which a certain set of actors can initiate this type of FLA to strengthen their position by changing the IPGS itself or with the intention to induce changes in other sub-systems of the NIS to improve

9 This hypothesis is obviously based on the auxiliary assumption that the FLA project is conducted in a methodologically appropriate way. Henceforth FLA (in singular) denotes an FLA project, with its chosen approach and methods. These two terms, thus, are used interchangeably. 
performance. In contrast, an oligopolistic IPGS would be more compatible with an FLA aimed at setting thematic priorities, launched by the dominant actors. That FLA would further strengthen the position of these actors. Further, the same type of FLA would better fit into a consensual IPGS, because a transformative FLA, that is, the one aimed at inducing systemic changes, would most likely increase tensions among the key stakeholders, and that would be against the main cultural feature of a consensual IPGS. Finally, the third dimension of IPGSs, namely reliance on strategic policy intelligence seems to be neutral vis-à-vis this type of FLA: where PPTs are used systematically, FLA could be launched either for inducing systemic changes (but in that case mainly to transform specific sub-systems of NIS, other than the IPGS itself because the systematic use of PPTs is an indication of a reasonably well functioning IPGS) or setting priorities. In the case of systematic use of PPTs an FLA can be made highly visible by disseminating its results in high profile reports, posting well-written highlights at widely visited websites, organising press conferences, seminars and other events attended by well-known experts, opinion leaders, high-ranking policy-makers and politicians.

The Greek National Technology Foresight Programme, one of the cases presented in more detail in the next section to illustrate the possible use of our framework, can be positioned in between two ideal types of our tentative taxonomy, namely an FLA Task Force and FLA Dialogue, given its moderately participatory nature. It is no surprise at all that an actual case 'sits' in between ideal types.

FLA Analysis: Fairly similar considerations apply to this type of FLA, except for its visibility. In this case there would be either no dedicated efforts to make it highly visible, or these efforts would not be successful for some reasons, e.g. given the richness of the PPT palette.

The other two types of the above four, namely FLA Dialogue and FLA Culture are characterised in more detail in the next section by describing real-life cases, that is, Hungary's TEP, and Germany's BMBF Foresight, respectively.

\section{ILLUSTRATIVE CASES}

To illustrate how to use our proposed framework for ex-post evaluations, we analyse three cases below, by answering a basic question, followed by subsequent ones.

- Has this FLA, according to an external evaluation, had a systemic impact?

- If yes, how well has the nature of the FLA fitted with the IPGS dimensions? Have any other success factors been identified? 
- If not, what have been the reasons? To what extent has a mismatch between the FLA and IPGS dimensions been observed? Have any other barriers that prevented a systemic impact from occurring been identified?

\subsection{GREECE: THE NATIONAL TECHNOLOGY FORESIGHT PROGRAMME}

The Greek National Technology Foresight Programme (NTFP) was the first large-scale foresight programme in Greece. It was conducted between 2001-2005 under the responsibility of the General Secretariat for Research and Technology (GSRT) of the Ministry of Development. The focus of the foresight was in particular on the question how science and technology could contribute to building a knowledge society with a 20-year time horizon (Damvakeraki, 2005).

Around the turn of the millennium, Greece was aiming to catch up with the more advanced countries of the EU. The Greek innovation system was characterised by fragmentation, a low level of business research and innovation efforts, and insufficient co-operation between businesses and academia. Further, innovators had to shoulder high administrative burdens (Amanatidou, 2013). Hence, it performed rather poorly in several regards. The research system was dominated by the public sector (i.e. universities and public research institutes), while the largest economic sectors (i.e. tourism, ship building) were not R\&D intensive.

Against this backdrop, the aim of the GSRT to use the foresight programme as a means to prepare a systemic change towards a knowledge society was rather ambitious, indeed.

Similar to the innovation system, the Greek innovation policy governance sub-system was quite fragmented and distributed at the turn of the millennium. The GRST may have been the dominant government actor in shaping STI policies but its influence on the strategies of the key research performing organisations was rather limited. Moreover, innovation-related agendas were also influenced by the Secretariat for Industry (GSI), while the significant share of the EU Structural Funds in government expenditures on RTDI was controlled by the Ministry of Economy and Finance (MEF). In terms of political-administrative culture, the terrain was clearly demarcated, with limited space for consultation with other ministries or participation of stakeholders in the definition of STI policy. Political decision-making largely took place 'behind closed doors' (Amanatidou, 2013), leaving limited room for consensus building and policy coordination. Overall, the culture is to be characterised as rather antagonistic.

The National Technology Foresight Programme (NTFP) mainly aimed at developing guidelines and assisting the government in designing the national STI policy strategy and supporting businesses in their strategic planning processes. This effort was also planned to lead to the establishment of a national foresight observatory; an ambition that was never 
materialised. The foresight process was panel-based, with 13 thematic panels and five crosscutting ones. While there was quite some interest in the open call for experts to participate (700 expressions of interest were received), panel composition was dominated by academics, with rather limited participation of business, government and societal experts. Panel-based work was complemented by 'top-down' scenarios to frame the work of the panels (GSRT, 2005). While the set-up of the process can indeed be characterised as highly participatory, the imbalance in terms of panel composition, as well as the rather traditional style of running most panels, which gave room to limited engagement only, clearly limited the participatory nature of the entire process. Overall, it can be characterised as moderately participatory. In general, Greece had very limited experience with foresight and other participatory methods. In fact, the use of policy preparatory tools (e.g. evaluation, impact assessments, benchmarking, etc.) to inform policy-making was also limited. The unique character of NTFP and the extensive dissemination activities towards the end of the process made the Greek national foresight a highly visible endeavour.

With hindsight, the initial ambitions were at best partially achieved (Amanatidou, 2009, 2013). Some specific collaboration between experts from different areas was triggered in the context of the exercise, but the limited involvement of private sector actors restricted the scope for forging new links in the innovation system. Fragmentation in the innovation system could not be overcome. Neither were bridges built across different innovation-related policy fields, mainly because the NTFP was largely perceived as an internal exercise of GRST.

While the quality of results was varying a lot across panels, often depending on the leadership by the chairs and rapporteurs, recommendations were often perceived as too general: not practical and specific enough for the advancement of the panel areas. Attention to innovation was limited by the fact that it was addressed by a dedicated panel, but not as a cross-cutting matter for all the thematic panels. In spite of a timely delivery of results, their take-up in policymaking was quite limited, not least due to the fact that priorities were not formulated in a sufficiently clear manner. The change in government in 2004 further contributed to delaying any follow-up actions. The longer-term ambitions of creating a foresight observatory and a foresight culture in Greece were not achieved. However, the open and participatory elements of NTFP showed that the preparation of policy decisions does not necessarily have to take place behind closed doors.

The reasons for the limited success and impact of NTFP are manifold, but can be summarised in three groups. First, given the absence of prior experience with foresight, insufficient time and effort was spent on 'preparing the ground' for a large-scale foresight process. Smaller steps might have been more appropriate to build the necessary capabilities and 
experience - both in terms of conducting foresight and absorbing its recommendations. The NTFP was thus overambitious; there was a mismatch between the ambitions of the programme and the context in which it was performed.

The shortcomings of methods and implementation should be added as a second reason. Membership of panels was imbalanced; traditional formats of interaction were chosen, and the implementation across panels was rather incoherent. The quality and specificity of results depended very much on the capabilities of rapporteurs, in particular. Overall, results were thus not interesting enough either for policy-makers, or business leaders. This was partly due to limited experience, training and preparation of the participants. The International Advisory Committee could have been used more extensively to support and guide the entire process.

A third major issue relates to communication and dissemination of results. Inadequate efforts were made to translate panel results into useful insights and inputs for industry, with innovation playing a marginal role only. Communication between the client and the contractor was scant; policy-makers were involved too late in the process and not as 'co-producers' of policy proposals. Overall, they did not have a real sense of ownership of the results, also because of the rather general character of many panel reports. Hence, the GSRT as the main client showed halfhearted commitment to the results, and there was no other foresight champion at a high political level to promote their use. It also needs to be acknowledged that the results of some panels (e.g. defence, health) were taken up in subsequent policy actions, but more could have been achieved with a different design and set up of the Greek NFTP.

\subsection{HUNGARY: TEP}

The Hungarian Technology Foresight Programme (TEP) was conducted in 1997-2000; that is, the first foresight programme in a former centrally planned economy. At that time the IPGS was oligopolistic (a few, centralised STI policy-making bodies at the national level, and hardly any decision-making competences at the regional level) with a prevailing antagonistic politicaladministrative culture. Some advanced policy-preparation tools (monitoring, system analysis, self-evaluation of a few policy tools) were used in an ad hoc manner, which was actually an achievement in a Central European context (compared to hardly any use of these tools until the late 1980 s, early 1990 s in these countries).

It is in this governance context that TEP was launched. The size of the country and the level of economic and social development played a decisive role in setting the objectives of the programme: it was driven by broad socio-economic needs and problems, rather than a narrow 
S\&T agenda. ${ }^{10}$ The overall objective of TEP was to contribute to a strategy for a socially, economically and environmentally sustainable development. More specifically, six goals were defined by the Steering Group: (i) contribute to a national innovation strategy based on a comprehensive analysis; (ii) help Hungarian firms improve their competitiveness by providing the results of this strategic analysis; (iii) strengthen the formal and informal relationships among researchers, business people and civil servants; (iv) spread co-operative and strategic thinking; (v) support integration into the European Union; (vi) formulate recommendations for public policies. In other words, setting thematic priorities was part of a broader set of objectives, among which inducing systemic changes was perceived at least as important (if not more) as identifying new market and technological opportunities.

Fundamental organisations and institutions were still being shaped in Hungary in the late 1990s, given the transition process: the country was set free from the former Soviet bloc and attempted to join the EU, which was also in a middle of a major transition process. Thus the wider, international context, where Hungary was trying to find her room, was also changing. It was perceived as a crucial task to analyse this turbulent environment, hence a strong emphasis was put on devising multiple futures, both at macro level (socio-economic framework conditions) and at the level of panels (micro and meso level issues). It should be stressed that macro scenarios had not been developed in any other country engaged in foresight activities by 1997 (when TEP was designed).

The process was at its core based on the engagement of stakeholders in seven thematic panels, complemented by a Delphi survey, and a series of thematic workshops. TEP panels had the freedom to follow their own 'instincts', and given the transition context, they devoted a significant part of their time and interest to non-technological issues, e.g. organisational and institutional development, including regulatory issues, although most members were S\&T experts. Yet, faced with the pressures of the transition process in their day-to-day work, they understood the importance of non-technological issues. It was also reflected in the Delphistatements, the survey results, ${ }^{11}$ and thus in the policy recommendations.

Overall, TEP was a clearly visible FLA programme. It was based on a highly participatory approach and engaged a broad range of stakeholders. It pursued a double purpose, namely to

\footnotetext{
10 The legacy of the former socio-economic system, especially its all-pervasive hierarchical feature, had a strong impact on the major decisions on the organisation and management of TEP, too: it was decided that the Steering Group should not be directly influenced by the government agency that initiated and financed TEP; and the seven panels were also given a great deal of autonomy to break with the past in a highly visible and symbolic way.

11 This approach was validated by the respondents, too: more than half of the 'top 10' Delphi-statements - those deemed to be the most favourable ones by the respondents, i.e. with the highest combined socio-economic and S\&T impacts - were non-technological in their nature (Havas, 2003: Table V).
} 
identify thematic priorities, but as part of a broader ambition to induce systemic changes needed for establishing an innovation system that allows combining technological opportunities successfully with market needs, and eventually contributes to improving the quality of life.

TEP was evaluated by an international team of experts in 2004. The evaluation report was based on interviews with key stakeholders as well as a survey (with 62 respondents, including 8 members of the Steering Group and 33 panel members, altogether 66\% of the respondents). Over $60 \%$ of respondents saw high or very high effect in establishing a longer-term perspective and over 50\% of them in formation of new networks (Georghiou et al., 2004: Figure 1). Thus, at least some systemic changes have been identified.

As for impacts on policy, the evaluation report made a distinction between direct and indirect impacts:

"The effects on public policy appear to have been much greater but were missed by initial analyses because they took much longer than expected to materialize - as one interviewee who was a policy user put it 'a slow and non-linear process'." (ibid: 5)

The report also "indicates an impact both on the climate of thought in many policy areas and a series of indirect but significant effects on policy in several domains. It seems that TEP created a reservoir of knowledge that entered the policy system in a non-linear fashion, either through personal networks of participants or simply by having cogent text available when policies were being drafted. A note of caution needs to be sounded on causality - TEP reflected as well as initiated the policy discourse in Hungary. However, the specificity of the impacts suggests that it at least crystallized and almost certainly extended significantly thinking on many issues." (ibid: 6)

The antagonistic political-administrative culture prevailing in the IPGS was a major cause of a lack of more visible direct impacts:

"The reasons for lack of direct implementation lie, we believe in the implementation environment in which the programme was situated. Its origins within the OMFB [the main STI policy-making body, that funded TEP] may initially have given it a welcome degree of freedom but with the radical change in nature of that organization and a change of government, ${ }^{12}$ there was no natural channel, nor an obvious champion in government able to act upon the results. Even if OMFB had been unchanged, it was itself at a distance from some of the political decisions implied in the recommendations. (...) The problem was (...) lack of ownership of the results and hence commitment to acting upon them. As it turned out TEP had no clear client base that felt its questions were being answered, a situation made worse by the discontinuity resulting from political change." (ibid: 6)

\footnotetext{
12 The government changed in 1998, and OMFB was fundamentally reorganised in January 2000 (became a division of the Ministry of Education from a stand-alone government office). Then the government changed again in 2002 and a new body, called National Office for Research and Technology was set up in 2004, that is, again a stand-alone government office.
} 
It seems that given the specific context of transition, in which it was important to stress the autonomy of TEP, ${ }^{13}$ there was a trade-off between intellectual freedom and the chance for greater impacts:

"While greater engagement by some ministries would have been beneficial, reporting to them directly could have constrained thinking and lost the benefit of multidisciplinarity within panels and learning generated through interaction between them." (ibid: 6)

With hindsight, probably it is more useful to run an FLA with the potential of having some limited, 'non-linear', indirect, and 'cultural' impacts than wait for 'ideal' circumstances. Had further FLA projects followed TEP, it would have been fairly easy to claim that introducing this new way of thinking - setting important changes in motion - is worthwhile even at the price of limited success for the first endeavour. Yet, the first ever foresight programme launched in a former centrally planned economy has not been followed by any other major forward-looking activity for 15 years by now - not even at the request of the European Commission to devise a socalled smart specialisation strategy, preferably underpinned by a foresight programme, as a socalled ex-ante conditionality to get access to the EU Structural Funds in 2014-2020. That certainly begs a fundamental question: what factors has caused this apparent failure? Answering this question, however, would require a separate - and possibly lengthy - paper.

\subsection{GERMANY: BMBF FORESIGHT}

The German BMBF foresight was launched in 2007. This two-year process was the first of a series that should evolve into a revolving process of exploring future issues and challenges to underpin German STI policy (BMBF, 2008). Indeed, a second phase was launched in 2012, which is not considered in this analysis.

The German innovation policy governance sub-system (IPGS) is a complex one, not least due to the federal structure of the country, with important responsibilities (e.g. for education and universities) residing with the Federal States. BMBF, the Federal Ministry for Education and Research has major competences in devising research policies and is also funding important research programmes. The excellence initiative to provide top-up funding to leading universities and research centres, together with the High-Tech Strategy, intended to concentrate RTDI efforts on key areas of future promise, are important elements of the federal STI policy (BMBF, 2006), aiming to guide and structure the overall evolution of the German innovation system.

In terms of centralisation, the IPGS may thus have several poles, but it nevertheless resides on some major pillars. There are large research organisations (Fraunhofer, Helmholtz, Max

\footnotetext{
13 On purpose, TEP was set up as a programme controlled by non-governmental experts, and in turn, the Steering Group delegated a great deal of autonomy to the panels.
} 
Planck) playing a key role in conducting research next to universities and industry. Industrial research, while in general being widely spread, is nevertheless dominated by the activities of some big players (Volkswagen, Siemens, large chemical firms, and the like), who are regularly consulted on matters of STI policy. Universities and some major research funding bodies (e.g. DFG) are also involved in shaping STI policies. German federalism injects an element of decentralisation into the IPGS, but in general the German IPGS can nevertheless be characterised as oligopolistic. The compartmentalisation of policy domains is generally quite pronounced, even if explicit efforts have been made for many years to overcome dissociated research (and STI policy) domains. In fact, both the High-Tech Strategy and the BMBF foresight aimed at building bridges between fields of research, research funding and - to some extent sectoral policies (BMBF 2006; Cuhls et al., 2009). The political-administrative culture can thus be regarded as quite antagonistic, both within the STI policy domain and between STI and sectoral policies. Foresight is just one element in a broad spectrum of PPTs used to underpin German STI policy. A broad spectrum of innovation system analysis is available, with dedicated bodies advising the government on STI policy matters, ${ }^{14}$ and policy evaluations are conducted regularly. The extent, to which recommendations are followed, varies; in any case, German STI policy has at its disposal a broad range of internal expertise, to interpret and learn from a systematic and regular use of PPTs.

The first phase of the BMBF foresight (2007-2009) was closely connected to the High-Tech Strategy (HST), aimed at advancing the new approach to STI policy inherent to the HST. Against this backdrop, the BMBF foresight pursued four main objectives:

- identify new focal areas in research and technology that the BMBF should address;

- define cross-cutting issues and interdisciplinary topics that require broader attention;

- help forge strategic partnerships of various departments within the ministry and different groups of RTDI actors in the innovation system, able to jointly address the areas and topics identified in a strategic manner;

- propose priorities for concrete measures to be adopted to promote the fields in question.

A combination of analytical and exploratory methods was applied, namely expert survey and participation, critical reflection and co-shaping of policy advice. A first, largely analytical phase delivered an overview of emerging future topics. It was consolidated by an on-line Delphi survey and followed by a series of workshops, designed to deliver the necessary 'sense-making'. Finally, 14 future RTDI topics and 7 cross-cutting future fields were identified, and suggestions were also

\footnotetext{
14 The Commission of Experts for Research and Innovation (EFI) is an important example.
} 
made regarding actors to be involved, partnerships to be formed, and actions to be taken (Cuhls et al., 2009; Cuhls, 2010).

Close interaction between the $\mathrm{BMBF}$ and the project team was established in order to facilitate the refinement and integration of findings in the ministry's strategy and policies (Cuhls et al., 2008; Cuhls, 2013). While the future topics could be integrated comparatively easily in the thematic research strategies, this turned out to be more difficult for cross-cutting future fields, which were rather orthogonal to the organisational structure of the ministry. However, at least one new division was created in BMBF, focussing on cross-cutting issues (Demographic Change; Human-Technology Co-operation), while another one has attracted quite a lot of attention in policy debates (ProductionConsumption 2.0) (Cuhls 2013). Further impacts remain to be seen.

Overall, the BMBF foresight can be regarded as having quite high visibility, while at the same time being embedded in an advanced forward-looking and strategic culture in policy-making. It builds on a long long-standing tradition of foresight activities using different approaches since the late 1970s, and - as a large-scale activity tied to the High-Tech Strategy - attracted a lot of interest from stakeholders. The degree of participation was quite high, even if more emphasis was put on expert stakeholders than, for instance, in the earlier FUTUR process, where broader engagement was realised. The on-line survey (with 2,659 participants), the international advisory panel, and the range of sense-making and strategy workshops conducted ensured a good embedding. Much emphasis was put on frequent interaction with policy-makers.

Returning to the intention and expected impact of BMBF foresight, and the aim to help support implementing the High-Tech Strategy, one can argue that policy-makers have indeed taken up several foresight suggestions, but that the expected structural impact in terms of crosscutting fields and approaches to STI policy has remained - thus far - limited. Addressing crosscutting issues is difficult in an environment characterised by an antagonistic politicaladministrative culture, demarcated terrains of S\&T fields, and a rather monolithic culture with limited openness to interdisciplinary approaches. However, there are some examples of interdisciplinary research that found a proper place in STI policy as dedicated organisational building blocks or major items in the political discourse. The ambitions have, thus far, only partly been met, but longer-term impacts cannot yet be assessed.

While the cross-cutting future fields may have encountered a limited success only, the overall impact of the BMBF foresight was quite remarkable due to the uptake of results from the 14 RTDI topics. Overall, the 'embedding' of highly innovative cross-cutting future fields in a process that offers also a number of 'quick wins' for more traditional RTDI topics, may actually have 
been a wise approach. It allowed infusing some non-conventional insights, maybe even counter to the prevailing IPGS, in a context that was otherwise mainly receptive to conventional RTDI topics.

The BMBF foresight managed to avoid the fate of foresight projects in other countries (among which were e.g. Greece and Hungary) where changes in government significantly reduced the chances of foresight recommendations to be taken up in policies pursued by the new government. This is because the BMBF Foresight was not tied to any particular political goal; its results can be used for different kinds of strategy formation processes. By preparing emerging topics with a significant potential for exploitation, it still leaves enough room for political choices to be taken. ${ }^{15}$

Dedicated efforts were made to interact closely with the sponsors of the BMBF foresight. In fact, it was expected from the foresight team to engage intensely with different interested parties at BMBF. This interaction was a meandering during the search and discovery process of new topics, which - as a side effect - strengthened the interactions and debates within and across government departments.

While the immediate structural and organisational impact may thus have been limited, BMBF Foresight opened up several first niches for cross-cutting future fields. Others may not have been taken up prominently, but continue to be debated, as a reservoir for further systemic change. If the process is continued on a regular basis as planned, these niches and reservoir fields may get reinforced during the next cycle(s).

\section{CONCLUSIONS}

This paper has proposed a conceptual framework for exploring the potential impact of FLAs that rests on different key features ('dimensions') of innovation governance sub-systems (IPGSs) and that of FLAs. The main purpose of constructing these taxonomies has been to explore which types of FLAs are compatible with which expression of the different IPGS dimensions. To reduce the complexity of this 'speculative' analysis, only those FLAs have been explored that are aimed at inducing systemic changes. This type of FLAs can be instrumental when - from a societal point of view - a radical change would be desirable, for instance to overcome a lock-in into traditional sectors, introduce a regime-shifting technology, or overhaul the IPGS itself (e.g. to change the STI policy rationale followed and/or the overall decision-making culture and

15 This reasoning does not suggest that other national foresight programmes have been tied to any particular political goal. 
methods used to underpin policy actions, improve the efficacy of STI policies and efficiency of public spending). Four different ideal types of such FLAs have been identified, one of which is characterised in an abstract way only, while the other three types have been examined in more detail by evaluating real-life FLA programmes. The three cases considered illustrate the usefulness of our proposed analytical framework for understanding the extent to which the 'match' between the FLA approach chosen and the key features of the IPGS has contributed to the intended changes in the respective NIS - or the 'mismatch', together with some other factors, has restricted the desired impacts.

This type of analysis, when applied thoroughly and honestly, can deliver some wellsubstantiated hypotheses/ insights into the appropriateness of a chosen FLA approach, that is, a 'fit' between a particular FLA and the innovation policy governance sub-system. The main hypothesis put forward has been that the closer the fit, the stronger and more favourable impacts of FLAs can be expected (obviously assuming an appropriate quality and methodological rigour in conducting the FLA project). Further specific hypotheses could also be formulated, and several of them could offer a number of guiding principles for the design of future FLAs.

Although the paper has focussed on national innovations systems, and therefore considered FLAs conducted at that level, this framework can be extended to sectoral and regional innovation systems, too.

Obviously, no framework can ever guarantee that an actual FLA is going to have favourable impacts, even when it is theoretically sound, and thus compelling to STI policy-makers and FLA participants. Context does matter for FLAs, too, and political or economic events/ developments can override an appropriate, seemingly perfect FLA design.

Ideally, an FLA should not be launched just because it is fashionable to do so - 'our neighbours/ competitors have done it, and we should be seen at least as advanced' - but to tackle a perceived policy need or create/ exploit new opportunities. In light of that, decisionmakers, as well as FLA practitioners and analysts should keep in mind that policy needs, FLAs and IPGSs interact in several ways. First, an often neglected impact of FLAs is that the understanding of the originally targeted policy needs /options would need to be revised, and new policy needs/ options are likely to be identified while conducting an FLA, which may, in turn, shift the character of a next FLA (assuming that the IPGS remains rather stable in the meantime). An obvious case in point would be the changing character of the UK foresight 
programme through its three cycles. ${ }^{16}$ Second, FLAs would impact on the innovation policy governance sub-system itself, at least in the longer term: a non-participatory FLA would reinforce the 'closeness' of an IPGS (its reliance on expert-based approaches), while a participatory FLA would open up a 'closed', hierarchical IPGS in a longer run, and with some ensuing tensions, of course. Finally, analysts and decision-makers also need to ask themselves a broader question when a lack of 'fit' between the above three elements is observed: is this a mistake in the design of an FLA, or has it been designed in this way on purpose, for instance with the intention to 'irritate' the prevailing system and by doing so induce systemic changes by that FLA?

\section{REFERENCES}

Amanatidou, E. (2009): Greek National Technology Foresight Programme: Perceived Impacts and Success Factors, EFP Foresight Brief No. 162, Vienna: European Foresight Platform

Amanatidou, E. (2013): The Greek National Technology Foresight Programme: success is in the eye of the beholder, International Journal of Foresight and Innovation Policy, 9 (1): 67-92

Bauchspies, W.K., Croissant, J., Restivo, S. (2006): Science, Technology and Society: A Sociological Approach, Oxford: Blackwell Publishing

Bijker, W.E. (2010): How is technology made? - That is the question!, Cambridge Journal of Economics, 34 (1): 63-76

BMBF (2006): Die Hightech-Strategie für Deutschland, Bonn, Berlin: Bundesministerium für Bildung und Forschung

BMBF (2008): The BMBF Foresight Process, Bonn, Berlin: Bundesministerium für Bildung und Forschung

Cuhls, K. (2010): The German BMBF Foresight Process, EFP Foresight Brief No. 174, Vienna: European Foresight Platform

Cuhls, K. (2013): Foresight in Germany: Implications for Policy Making, in: Meissner, D. et al. (eds): Science, Technology and Innovation Policy for the Future, Heidelberg: Springer, pp. 199-217

Cuhls, K., Beyer-Kutzner, A., Bode, O., Ganz, W., Warnke, P. (2008): The BMBF Foresight Process, Third International Seville Seminar on Future-Oriented Technology Analysis: Impacts and implications for policy and decision-making, Sevilla, 16-17 October 2008

Cuhls, K., Ganz, W., Warnke, P. (eds) (2009): Foresight-Prozeß im Auftrag des BMBF, Zukunftsfelder neuen Zuschnitts, Karlsruhe, Stuttgart: Fraunhofer ISI, Fraunhofer IAO

Damvakeraki, T. (2005): Greek National Technology Foresight 2021, EFMN Foresight Brief No. 12, Vienna: European Foresight Platform

\footnotetext{
${ }^{16}$ As thorough analyses of the UK foresight cycles are readily available (among others, Georghiou et al., 2010; Keenan and Miles, 2008; and Miles, 2005), here suffice it to recall briefly that the first cycle was aimed at identifying S\&T priorities for the entire UK research system; the second was concerned with promoting a broader participation in dialogues on business-related issues via mobilising a wider variety of participants, and also broadening the issues considered, especially by putting more emphasis on quality of life; while the third significantly changed the scope of analyses to anticipate policy-relevant changes and identify how S\&T can serve these direct, sharply focussed policy needs (e.g. tackle flooding, cyber crime and obesity), restricted the number of projects running at any one time (to three to four), as well as the time available to complete a given project (to 12-18 months).
} 
Dosi, G. (1988): The nature of the innovative process, in: Dosi et al. (eds), pp. 221-238

Dosi, G., Freeman, C., Nelson, R.R., Silverberg, G., Soete L. (eds) (1988): Technical Change and Economic Theory, London: Pinter

Edquist, C. (ed.) (1997): Systems of Innovations: Technologies, institutions and organizations, London: Pinter

Edquist, C. (2011): Design of innovation policy through diagnostic analysis: identification of systemic problems (or failures), Industrial and Corporate Change, 20 (6): 1725-1753

Fagerberg, J., Mowery, D.C., Nelson, R.R. (eds) (2005): The Oxford Handbook of Innovation, Oxford: Oxford University Press

Fagerberg, J., Fosaas, M., Sapprasert, K. (2012): Innovation: Exploring the knowledge base, Research Policy, 41 (7): 1132-1153

Freeman, C. (1991): Networks of innovators, a synthesis of research issues, Research Policy, 20 (5): 499-514

Freeman, C. (1994): The economics of technical change: A critical survey, Cambridge Journal of Economics, 18 (5): 463-514

Freeman, C. (1995): The "National System of Innovation" in historical perspective, Cambridge Journal of Economics, 19 (1): 5-24

Georghiou, L. (2001): Third generation foresight - integrating the socio-economic dimension, Proceedings of the International Conference on Technology Foresight - The Approach to and Potential for New Technology Foresight, NISTEP Research Material 77, March, NISTEP, Tokyo, http://www.nistep.go.jp/achiev/ftx/eng/mato77e/html/mato771e.html

Georghiou, L. et al. (2004): Evaluation of the Hungarian Technology Foresight Programme (TEP) - Report of an International Panel, http://pdc.ceu.hu/archive/0000269o/

Georghiou, L., Cassingena Harper, J., Keenan, M., Miles, I., Popper, R. (eds) (2008): The Handbook of Technology Foresight: Concepts and Practice, Cheltenham: Edward Elgar

Georghiou, L., Keenan, M., Miles, I. (2010): Assessing the impact of the UK's evolving national foresight programme, International Journal of Foresight and Innovation Policy, 6 (1/2/3): $131-150$

GSRT (2005): Technology Foresight in Greece: Summary, Athens: General Secretariat for Research and Technology

Hackett, E.J., Amsterdamska, O., Lynch, M., Wajcman, J. (eds) (2008): The Handbook of Science and Technology Studies, $3^{\text {rd }}$ edition, Cambridge, MA: The MIT Press

Haegeman, K., Marinelli, E., Scapolo, F., Ricci, A., Sokolov, A. (2013): Quantitative and qualitative approaches in Future-oriented Technology Analysis (FTA): From combination to integration?, Technological Forecasting and Social Change, 80 (3): 386-397

Hall, B.H., Rosenberg, N. (eds) (2010): Economics of Innovation, Amsterdam: North-Holland

Hall, P.A., Soskice, D. (eds) (2001): Varieties of Capitalism: The Institutional Foundations of Comparative Advantage, Oxford: Oxford University Press

Hall, P.A., Thelen, K. (2009): Institutional change in varieties of capitalism, Socio-Economic Review, 7 (1): 7-34

Havas, A. (2003): Evolving Foresight in a Small Transition Economy: The design, use and relevance of foresight methods in Hungary, Journal of Forecasting, 22 (2-3): 179-201

Havas, A. (2005): Terminology and Methodology for Benchmarking Foresight Programmes, report for the ForSociety Transnational Foresight ERA-Net project, http://papers.ssrn.com/sol3/papers.cfm?abstract $\mathrm{id}=1735023$ 
Havas, A. (2011): Governing Policy Processes and Foresight: Potential Contributions and Inherent Tensions, in: Banse, G., Grunwald, A., Hronszky, I., Nelson, G. (eds): On Prospective Technology Studies, Karlsruhe: KIT Scientific Publishing, pp. 1-18

Jasanoff, S., Markle, G.E., Petersen, J.C., Pinch, T. (eds) (1995): Handbook of Science and Technology Studies, Thousand Oaks, CA: Sage

Joerges, B., Nowotny, H. (eds) (2003): Social Studies of Science and Technology: Looking Back, Ahead, Dordrecht: Springer

Keenan, M., Miles, I. (2008): Foresight in the United Kingdom, in: Georghiou, L. et al. (eds), pp. 91-111

Kuhlmann, S. (2001): Management of innovation systems: The role of distributed intelligence, Antwerp: Maklu Uitgevers N.V.

Latour, B. (2005): Reassembling the Social: An Introduction to Actor-Network Theory, Oxford: Oxford University Press

Lundvall, B-Å. (ed.) (1992): National Systems of Innovation: Towards a Theory of Innovation and Interactive Learning, London: Pinter

Lundvall, B-Å., Borrás, S. (1999): The Globalising Learning Economy: Implications for Innovation Policy, Luxembourg: Office for Official Publications of the European Communities

Malerba, F. (2009): Increase learning, break knowledge lock-ins and foster dynamic complementarities: evolutionary and system perspectives on technology policy in industrial dynamics, in: Foray, D. (ed.): The New Economics of Technology Policy, Cheltenham: Edward Elgar, pp. 33-45

Martin, B. (2012): The evolution of science policy and innovation studies, Research Policy, 41 (7): 1219-1239

Martin, B., Johnston, R. (1999): Technology Foresight for Wiring Up the National Innovation System: Experiences in Britain, Australia, and New Zealand, Technological Forecasting and Social Change, 60 (1): 37-54

Metcalfe, J.S. (1998): Evolutionary Economics and Creative Destruction, London: Routledge

Metcalfe, J.S. (2005): Systems failure and the case for innovation policy, in: Llerena, P., Matt, M. (eds): Innovation Policy in a Knowledge-Based Economy: Theory and Practice, Heidelberg: Springer, pp. 47-74

Metcalfe, J.S., Georghiou, L. (1998): Equilibrium and evolutionary foundations of technology policy, STI Review, No. 22, pp. 75-100

Miles, I. (2005): UK Foresight: three cycles on a highway, International Journal of Foresight and Innovation Policy, 2 (1): 1-34

Miles, I., Cassingena Harper, J., Georghiou, L., Keenan, M., Popper, R. (2008): The many faces of foresight, in: Georghiou, L. et al. (eds), pp. 3-23

Nelson, R.R. (ed.) (1993): National Innovation Systems: A comparative study, New York: Oxford UP

Nelson, R.R. (1995): Recent evolutionary theorizing about economic change, Journal of Economic Literature, 33 (1): 48-90

Pavitt, K. (1999): Technology, Management and Systems of Innovation, Cheltenham: Edward Elgar

Peters, B.G., Pierre, J. (1998): Governance Without Government: Rethinking Public Administration, Journal of Public Administration Research and Theory, 8 (2): 223-243

Rhodes, R.W.A. (1997): Understanding Governance: Policy Networks, Reflexivity and Accountability, Buckingham: Open University Press 
Smith, K. (2000): Innovation as a Systemic Phenomenon: Rethinking the Role of Policy, Enterprise \& Innovation Management Studies, 1 (1): 73-102

Smith, K. (2002): What is the "Knowledge Economy"? Knowledge intensity and distributed knowledge bases, UNU/INTECH Discussion Paper Series, 2002-6

Tidd, J., Bessant, J., Pavitt, K. (1997): Managing Innovation: Integrating technological, market and organizational change, Chichester: John Wiley \& Sons

Weber, M. (2009): FTI-Politik im Spiegel von Theorie und Praxis: von Planung über Steuerung zu Governance, in: Leitner, K.-H., Weber, M., Fröhlich, J. (eds): Innovationsforschung und Technologiepolitik in Österreich, Innsbruck: Studienverlag, pp. 231-254

Willke, H. (1995): Systemtheorie III: Steuerungstheorie, Grundzüge einer Theorie der Steuerung komplexer Sozialsysteme, Stuttgart: Fischer 